\title{
Information technology and class action notification
}

\author{
Vladimir Dolganichev ${ }^{1 *}$ \\ Department of civil procedure, Ural State Law University, 620137, Yekaterinburg, Russia
}

\begin{abstract}
The article discusses the use of information technology for class action notification. The author analyzes the foreign experience of using information technology to notify potential group members about a class action field. In international practice, there are two ways of notification: public and individual. In both cases, the capabilities of the Internet can be used. So, a public notice involves non-personalized notification of the alleged group members. A public notice can be implemented, for example, by posting information about a class action on various sites, banners. It is also possible to use the social networks of the defendant or the plaintiff-representative. Individual notification in this context can be implemented via e-mail and social networks, and their messengers. As a result of the analysis of the Russian legislation on class actions regarding the notification of potential participants, the author notes the heterogeneity of procedural mechanisms for sending notifications and the limited use of information technologies.
\end{abstract}

\section{Introduction}

Class actions have long become elements of modern procedural systems and services to protect not only "traditional" subjective rights. Class actions have become a means of defense for numerous groups of individuals whose rights and interests have been violated on the Internet. Examples of such claims are claims brought against Facebook and Google in connection with the acquisition and dissemination of users' personal data.

At the same time, even though class actions are designed to protect "new" rights and legitimate interests, for a long time, this procedural institution did not use new information technologies to ensure the most efficient and fast work. At the present stage, information technologies are actively being introduced into the field of legal proceedings. The institution of class action in this regard does not stand aside. Information technology is generally used when considering class actions, including filing a claim, notifying potential participants in a class action, and forming a group (maintaining a register of participants). The most important task of group production is the task of forming a group, the solution of which is impossible without notifying the group members. That is why in this article, we focus on the possibility of using information technology to notify potential members of a large group of people.

\section{Group claim notification models}

Notice in class actions plays an important role. They allow notifying all potentially interested persons to ensure the formation of a group. Consequently, notices provide protection for multiple individuals and avoid multiple separate proceedings by individuals who were members of the group but did not know that the class action was being filed.

The procedural legislation of various countries to notify potential participants in a class action provides the opportunity to use both individual and public notices. Traditionally, the mechanism of sending notifications by mail with a return receipt was used as a particular notification method, publication in various media as a public method of notification. Various combinations of these methods (several individual and public) are also used [1]. It is the combination of methods that is recognized as the most correct and ensures compliance with the doctrine of due process of law and jurisprudence.

\subsection{US and Australian experience}

Naturally, new methods of notification are associated with the use of the Internet. Notification over the Internet can be made in a variety of ways, both individually and publicly. Banners can be placed on the desired site. The notices themselves can be published on sites that the group members are likely to visit. Also, notifications can be sent to the e-mail of the group members directly. As is the case with traditional notification methods, a combination of different methods can be used. The Internet is rapidly becoming the mainstay of class action notices in terms of a custom delivery mechanism. As a result, more potential group members may find out about the class action [2].

\subsubsection{Individual notifications}

Since the Internet is now ubiquitous and almost everyone has their e-mail address, individual class action filing

\footnotetext{
Corresponding author: dolganichev@ mail.ru.
} 
can be more effective and less costly by sending notices via e-mail.

While researching the use of e-mail to send notices, American researchers questioned whether the e-mail addresses of group members could be obtained through "reasonable effort." This issue is primarily a practical problem. One of the reasons why e-mail notification may not be practical is that not all people have e-mail addresses yet. Another problem is that the e-mail address does not automatically include the citizen's full name, which makes it potentially more difficult to find a specific e-mail address than a street address. The third reason is that there is no single directory of e-mail addresses [3].

As the use of e-mail becomes ubiquitous, class action defendants may have lists of group members' e-mail addresses that, like street addresses, the court can order to provide.

One of the most compelling reasons an e-mail notice meets the due process criterion is that it is comparable to return postage, the most common way of sending notices. The name "e-mail" alone proves the analogy. While e-mail and return-of-delivery mail are naturally not the same, the similarities are so evident that e-mail must comply with due process requirements as a returnof-delivery mail.

E-mail and traditional mailing are so similar because the procedures by which they are created and sent are parallel to one another. In both cases, the sending procedure begins with the creation of a text document by the sender. The sender then "sends" this document to a person at a specific address. A legacy mail service and an online e-mail service deliver the letter to the recipient's mailbox. Both letters "wait" in the recipient's mailbox until he checks it, then reads it [4].

Over time, American courts have come to understand that e-mail and Internet notification are acceptable means of delivering notices in a group proceeding. Moreover, courts are beginning to accept the contention that Internet notification may be preferable to traditional notification publishing methods.

This situation is typical not only of the countries of Anglo-Saxon law. The use of e-mail to notify group members is also allowed in Japan and the Netherlands [5].

One of the exciting ways to send individual notifications that have appeared in recent years is through social networks: Facebook, Twitter, and LinkedIn [6]. For example, the Australian Capital Territory's Supreme Court allowed participants in the proceedings, including class members, to be notified via Facebook messenger [7]. The authors point out that Facebook post notification would be helpful in addition to and cannot replace other direct forms of individual notification such as email or postal mail at this time. The reason is that some people do not use Facebook, and of those who do, not all use their official name as it appears on the class list; some people, for example, use fictitious names to protect their privacy. Another problem is that a person may not be serious about a notification received through Facebook. The above is similar to the problems of this method of notification with email notification.

\subsubsection{Public Notice}

The second method of notification is public. First of all, it involves the placement of relevant information on Internet sites.

For the United States, posting notices on dedicated Internet sites, which may be visited by group members and combine more detailed information, is a helpful addition to the individual notice [8] but can also be used separately. This posting of notices can be done at a relatively low cost and has recently become quite effective as the percentage of the population that regularly uses the Internet is constantly growing.

A myriad of sites provides information and links to class action lawsuits. On the one hand, these websites serve the same purpose as individual notices: to alert group members to a class action that will determine their rights and to include those group members in either a proceeding or settlement. On the other hand, these websites are educational portals that provide information on everything from the most basic rules to the most complex group production issues. These websites can be categorized into "independent websites containing neutral information," "independent websites containing motivational information," and "websites owned by law firms and containing incentive information" [2].

The first is that independent sites containing neutral information have no connection with any law firms or referral services. They provide information about class actions on their own. These sites act as clearinghouses through which absent group members and others can obtain information without fear of bias or distortion. These websites include FindLaw Class Action Center (http://classaction.fmdlaw.com), Class Action Lawsuits (http://www.web-access.net/--aclarklframes45.htm.), and Class Action Litigation Information (http.//www.classactionlitigation.com).

Independent websites that contain motivational information like the ones above provide class action information on their own. However, this information is not neutral. Although these sites do not provide services, they "sell ideas" [2]. This type of website is a blog, and both well-known scientists and legal practitioners maintain these blogs. Blogs address various group production issues (e.g., Mass Tort Litigation Blog, http://lawprofessors.typepad.com/mass-tort-litigation;

Products Liability Prof Blog, http./lawprofessors.typepad.com/products liability; Class Action Defense Blog, http://classactiondefense.jmbm.com).

The last type of sites are websites that are owned by law firms and contain motivating information. These sites provide potential plaintiffs with the opportunity to become members of class action lawsuits. These sites do not provide class action information per se. Instead, these sites engage customers by providing information on pending or potential class claims. Such websites are either moderated by law firms that specialize in representing plaintiffs or defendants in a group proceeding or by other interested companies. For example, Milberg LLP, http://www.milberg.com; Law Firm of Motley Rice LLC, http://www.motleyrice.com; 
Winston \& Strawn LLP, Class Actions, http://www.winston.com/index.cfm?contentlD=19\&item lD=274).

Returning to the possibility of using social media for class action notices, researchers and US courts also point out the permissibility of using Facebook as a public notification method [6].

Specifically, the ad may be posted on the defendant's Facebook profile page (Kelly v. Phiten USA, Inc., 277 F.R.D. (S.D. Iowa 2011)) or a class-action law firm. The court approved the notification plan by posting a message on the defendant Phiten's Facebook page in the trial Kelly v. Phiten USA. While as follows from the judicial act, the notification on the social network was not the only one - potential group members were notified by sending them individual notices via e-mail. Moreover, in this case, the traditional methods of notification were not used for notification. This case shows how people can successfully combine public and private notices using the resources of the Internet.

Thus, American science and practice determine a fairly large number of ways to notify potential members of a large group about a class action filed, including using the Internet. The development of ideas about the possibility of notification through information technology and the conclusion that such methods comply with the doctrine of due process [3] led to the fact that in 2018, Rule 23 of the Federal Civil Procedure Rules were amended, which currently allows the use of "electronic means" for class action notification [9].

\subsection{Russian experience}

Initially, we note that the rules for handling class actions are not contained in just one piece of legislation. The Arbitration Procedure Code of the Russian Federation (Chapter 28.2), the Civil Procedure Code of the Russian Federation (Chapter 22.3), and the Code of Administrative Procedure of the Russian Federation (Article 42) allow the use of a class action depending on the type of legal proceedings. The norms of the Arbitration Procedure Code of the Russian Federation and the Civil Procedure Code of the Russian Federation because of the class action reform of 2019 are almost identical. However, the rules of the Code of Administrative Procedure of the Russian Federation differ, including issues of notification of potential group members.

The Arbitration Procedural Code of the Russian Federation (Article 225.14) and the Civil Procedure Code of the Russian Federation (Article 244.26) establish as the primary method of notification in a class action - public notification by publishing a message in the media. Until November 1, 2019, the Arbitration Procedure Code of the Russian Federation allowed, along with the public and individual notice, by sending a registered letter with acknowledgment of receipt. It is also possible to consider a public method of notification posting relevant information about the filed class action on the website of the relevant court on the Internet. Only in exceptional cases is it allowed to request information about the group members from the defendant and send them the appropriate notifications [10].

In the Code of Administrative Procedure of the Russian Federation, there are no special rules for notification of class actions at all. Accordingly, notifications are allowed according to the general rules enshrined in Chapter 9 of the Code of Administrative Procedure of the Russian Federation. This circumstance means that only individual notices can be used in the form of registered letters and subpoenas with acknowledgment of receipt, telegrams and telephone messages, and facsimile communications. Unfortunately, it is impossible to use electronic communication means [11] (e-mail or SMS notification). The purpose is that these means do not allow "the court to make sure that the addressee has received a judicial notice." Even more so, they are allowed only with the person's consent indicated in the corresponding receipt. However, another important thing, in this case, is that often, potential group members cannot be identified. This circumstance may be especially relevant in cases of challenging regulatory legal acts, where the circle of potential participants is obviously not defined.

Analyzing the provisions of the Arbitration Procedural Code of the Russian Federation, the Civil Procedure Code of the Russian Federation, and the Code of Administrative Procedure of the Russian Federation concerning the methods of notification, it can be noted that the use of only one method of notification is insufficient. Why the plaintiff-representative, knowing the composition of the large group (or part of it), cannot use an individual notice in addition to the public one? This idea contrasts the US law's "best practice in appropriate circumstances" notices rule. It would be correct to fix both options in the procedural codes [12].

The problem with class action notification in Russia is the lack of use of information technology. Indeed, the Arbitration Procedure Code of the Russian Federation and the Civil Procedure Code of the Russian Federation indicates the possibility of posting a class action notice on the website of the respective court. However, how often do participants in civil and arbitration proceedings, administrative proceedings use the websites of the respective courts? The answer is rather negative. Even professional participants in the legal services market using only the services "My Arbiter" or the State Automated System "Justice." The possibility of placing a public notice on the court's website specified in the law is supplemented by the possibility of disputes on bringing the controlling person to subsidiary liability in the framework of bankruptcy cases, including the corresponding message in the Unified Federal Register of Bankruptcy Information (https://bankrot.fedresurs.ru). Unfortunately, for some reason, the experience of using this resource is not extended to the consideration of all cases of group proceedings.

As we said above, the use of information technology for public notice is not limited only to official Internet resources - in world practice, other resources are also used - various kinds of sites. In Russian jurisprudence, there are cases in which the issue of the admissibility of using various Internet resources for posting notices of a 
class action filed is considered. Thus, in case No. 2-729 / 2020, the Yegoryevsky City Court of the Moscow Region stated: "A publication on a website that is not a popular media outlet and has a different coverage area for potentially interested parties in the lawsuit under consideration should be considered inappropriate since it is not aimed at bringing information to an unlimited number of people. In addition, the publication of notices on websites does not provide an opportunity for the unambiguous perception and unimpeded recording of information by potential plaintiffs" (Determination of the Yegoryevsk City Court of the Moscow Region dated May 28, 2020, in case No. 2-729 / 2020). From the above, we can conclude that the court, in this case, considered the notice posted on the website inappropriate since it does not provide "broad involvement of the plaintiffs interested in the claim." Although, of course, the conclusion of the court is somewhat controversial. It seems that the opposite is true - traditional media (newspapers, television, and radio) are gradually losing their positions, new media, the platform of which is the Internet, are gaining more and more importance. And not using such a site is a significant omission.

A rule has appeared in the Arbitration Procedure Code of the Russian Federation and the Civil Procedure Code of the Russian Federation, according to which group members (primarily a person who has applied to protect the rights and legitimate interests of a group of persons) can agree on the procedure for incurring legal costs in a class action. Relevant information about class actions and the possibility of joining an already filed lawsuit can be posted. This rule should facilitate the involvement of the legal business in the scope of the class action. This circumstance would prompt be creating websites (or placement on existing ones) of law firms containing motivating information, similar to those described in clause 1.1.2 of this article. Another option is the emergence of specialized funds for financing class actions. For example, the PLATFORMA website (https://platforma-online.ru/) already contains information about the filed class actions. At the same time, as noted, the Russian procedural legislation does not consider such notification is appropriate.

It is even more challenging to talk about the possibility of using social media to notify potential class members than about using websites. There is only one reason - the publication of information on social networks is an inappropriate notification method. In Russia, the most frequently used social networks are Vkontakte, Odnoklassniki, and the same Facebook. Thus, in one of the cases, the court indicated that posting information on the Vkontakte social network could not correctly publish a proposal to join the claim. The purpose is such a proposal must be made by publishing a message in the media "(Determination of the Kirovsky District Court of 20.08.2020 in case No. 2-3435 / 2020). From the above, we can conclude, that formally, social networks are not mass media. Therefore, the choice of such a notification method does not comply with the law. At the same time, judicial practice does not offer convincing reasons why such a notification method is "inappropriate." This approach can also be found in the literature. Thus, it is noted that "some plaintiffs, however, show unnecessary creativity and post an offer to join in social networks. However, such a format, of course, is inappropriate" [13].

However, it seems that, as in the case of foreign experience, the use of several methods of notification, including the use of particular methods (e-mail), public methods (various kinds of sites, social networks), would give a better result.

At the same time, the reform of the Russian class action system was widely covered on the Internet on various platforms: from media sites (Izvestia, Kommersant) to sites of various law firms or even social networks for lawyers. In this regard, it would be helpful for Russian legal reality to use the information portals for lawyers "Zakon.ru" (https://zakon.ru) and "Pravo.ru" (https://pravo.ru), which have already been operating for several years. On these sites, it would be possible to create appropriate sections dedicated to group production. They would contain information about the class actions filed with a proposal to join, information about the person who claimed in defense of the group of persons, and about his representatives (lawyers). In addition, many well-known scholars and practicing lawyers blog on these sites, from where it will also be possible to obtain information about class claims and their practice.

\section{Conclusions}

Russian procedural legislation in terms of the rules for notification of class actions is heterogeneous: in one case, public notice is allowed; in the other, only the individual. In the context of the use of information technology, the rules for notifying potential group members are very limited. Thus, procedural legislation indicates the possibility of public notification (in the media). However, among other methods, it notes only the posting of information on the official websites of the respective courts. At the same time, the use of individual notifications using electronic almost and/or various kinds of messengers is not allowed. It should be admitted that the use of information technology in this area has been postponed for several years.

\section{References}

1. V.V. Dolganichev, The initiation and preparation of cases of group proceedings (Statut, Moscow, 2017)

2. R.H. Klonoff, M. Herrmann, B.W. Harrison, Making class actions work: the untapped potential of the Internet, University of Pittsburgh Law Review, 69, 730 (2007-2008).

3. Ch. Bartholomew, E-Notice, Duke Law Journal, 68(2), 242-243 (2018).

4. J. Mingus, E-mail: a constitutional (and economical) method of transmitting class action notice, Cleveland State Law Review, 47, 102 (1999). 
5. C. Sanger (ed.), The Class Actions Law Review, Third Edition, The Law Reviews, 125, 140 (2019).

6. A.W. Aiken, Class Action Notice in the Digital Age, University of Pennsylvania Law Review, 165, (2017).

7. A. L. Shultz, Superpoked and Served: Service of Process via Social Networking Sites, U. Rich. L. Rev., 43, 1497 (2009).

8. The Manual for Complex Litigation, Fourth. (Federal Judicial Center, 2004).

9. R. Marcus, Revolution v. Evolution in Class Action Reform, North Carolina Law Review, 96, (2018)

10. P. Zvier, V.V. Yarkov, Class actions in the legal history of the United States and Russia: in search of an optimal model, Herald of civil procedure, 10(1), 174-185 (2020).

11. I.N. Spitsin, Reform of the Judicial Notice and Summons Institution, Arbitrazh and Civil Procedure, 12, 32-34 (2017).

12. V. V. Dolganichev, Class Action: Comparative Analysis of the Regulatory Models of the Arbitrazh Procedure Code, Civil Procedure Code and Administrative Procedure Code, Zakon, 2, 36-45 (2021).

13. G. Ryabchikov, Features of a class action in the field of civil proceedings, Legal Reference Book of The Head, 4, 39-47 (2021). 